Pereira, H. G. \& Kelly, B. (1957). J. gen. Microbiol. 17, 517-524

\title{
Dose-response Gurves of Toxic and Infective Actions of Adenovirus in HeLa Cell Gultures
}

\author{
By H. G. PEREIRA* aNd BARBARA KELLY \\ Common Cold Research Unit, Harvard Hospital, Salisbury, Wiltshire
}

SUMMARY: Study of the dose-response curves in titrations of adenovirus type 5 in cultures of HeLa cells suggests two different mechanisms of cytopathic effect. A late effect, caused by relatively small virus doses, is considered to be a manifestation of virus infectivity and is in good agreement with the hypothesis of independent action of virus units in the initiation of infection. The early effect, on the other hand, requires large virus doses and is considered to be of a toxic nature. Infective and toxic properties of adenovirus type 5 are distinguished by the greater sensitivity of the latter to inactivation by ultraviolet light.

The methods used for infectivity titrations of adenoviruses are based on the cytopathic action of these agents in tissue cultures. Titration techniques described by different workers vary in several respects but in most cases the results are based on quantal responses in cultures incubated for a given period. A relationship between virus dose and time of onset of cytopathic effect has been described (Rowe, Huebner, Gilmore, Parrott \& Ward, 1953), and Kjellen (1956) developed a method of titration based on the latent period which precedes the cytopathic effect.

In the course of repeated titrations of adenovirus preparations we observed a difference between the slopes of dose-response curves of titrations read after varying periods of incubation. These differences suggest that the early effect of adenoviruses in $\mathrm{HeLa}$ cell cultures is of the nature of a toxic action, whereas the late effect is a manifestation of the infective property of the virus resulting from the independent action of single infective units.

Studies on the dose-response curves of bacterial and virus titrations have been extensively reviewed and discussed (Beard, Sharp \& Eckert, 1955; Bryan, 1955; Isaacs, 1957; Lauffer \& Price, 1945; Luria, 1940; Meynell \& Stocker, 1957). In most infectivity titrations the log dose-probit response curves show a slope equal to or lower than 2 (Peto, 1953), this being approximately the slope of the first term of the Poisson distribution (the 'one-particle curve'). This finding is generally accepted as evidence for the hypothesis of independent action of infective units, a single unit being sufficient to initiate infection. Deviations from the one-particle curve are attributed to variations in host susceptibility which cause a flattening of the curves. This is particularly evident with agents such as the tumour viruses where variation in host susceptibility greatly affects the slope of dose-response curves (Bryan, 1954; Beard et al. 1955). With bacteriophages, on the other hand, where host susceptibility is uniform, agreement with the one-particle curve is good (Feemster \& Wells, 1933; Luria,

* Present address: National Institute for Medical Research, Mill Hill, London, N.W. 7. 
1939). In the study of animal viruses host variation may be diminished by using tissue culture techniques and results agreeing with the hypothesis of independent action of virus units have been reported in titrations based on quantal responses (Sheffield \& Smith, 1956) and on plaque counts (Dulbecco, 1952).

The cytopathic effect of viruses in tissue cultures is in most cases a consequence of virus multiplication resulting in structural alterations of the host cell. It has, however, been demonstrated by Henle, Girardi \& Henle (1955) that influenza virus may cause a cytopathic effect not associated with reproduction of infective virus. This effect requires a large multiplicity of infection and probably depends on the synergistic action of virus particles. It is therefore to be expected that dose-response curves of titrations based on this cytotoxic effect in cultures of relatively uniform susceptibility should give a slope steeper than that of the one-particle curve. Our suggestion of a toxic nature for the early effect of adenovirus in HeLa cells was based on this reasoning. A further distinction between early and late effects observed in our titrations was provided by the greater resistance of the former to inactivation by ultraviolet light. Similar findings have been reported in connexion with the toxic effect of influenza viruses in animals (Henle, G. \& Henle, W., 1946; Henle, W. \& Henle, G., 1946, 1947) and in tissue cultures (Henle et al. 1955).

\section{METHODS}

HeLa cell cultures were propagated and maintained in the following media: medium I: $10 \%(\mathrm{v} / \mathrm{v})$ human serum, $0.5 \%(\mathrm{w} / \mathrm{v})$; lactalbumin hydrolysate (Nutritional Biochemical Corporation, Cleveland, Ohio); $0 \cdot 1 \%(\mathrm{w} / \mathrm{v})$ yeast extract (Difco) in balanced saline solution (Gey \& Gey, 1936). Medium II: $\mathbf{5} \%(\mathrm{v} / \mathrm{v})$ normal rabbit serum; $\mathbf{0 . 5} \%(\mathrm{w} / \mathrm{v})$ lactalbumin hydrolysate in balanced saline solution. Medium III: $5 \%(\mathrm{v} / \mathrm{v})$ normal rabbit serum; $\mathbf{0 . 2 5} \%(\mathrm{w} / \mathrm{v})$ lactalbumin hydrolysate in balanced solution. Penicillin (100 units/ml.), streptomycin (100 mg./ml.) and mycostatin (20 units $/ \mathrm{ml}$.) were added to all media. The balanced saline solution was prepared according to the formula given by Gey \& Gey (1936) except that the concentration of sodium bicarbonate was decreased to $1 \cdot 125 \mathrm{~g}$. $/ 1000 \mathrm{ml}$. Human serum was used in pools of three or four samples, filtered through GS sterimats and stored at $-15^{\circ}$. Rabbit serum was obtained from adult Dutch rabbits bled by heart puncture under ether anaesthesia. The serum was separated by centrifugation, heated at $60^{\circ}$ for $30 \mathrm{~min}$. and stored at $-15^{\circ}$. Lactalbumin hydrolysate was used as a $5 \%(\mathrm{w} / \mathrm{v})$ stock solution in calcium- and magnesium-free balanced saline solution, autoclaved at $8-9 \mathrm{lb} . / \mathrm{sq} . \mathrm{in}$. for $10 \mathrm{~min}$. A $1 \%(\mathrm{w} / \mathrm{v})$ stock solution of yeast extract was prepared similarly.

Stock HeLa cell cultures were grown in $250 \mathrm{ml}$. bottles incubated in a roller drum at $37^{\circ}$. Bottles containing about $10^{7}$ cells were each subcultured either to three new bottles or to 100 tubes by the following technique: the fluid medium was removed as completely as possible and $2.5 \mathrm{ml}$. of a $0.5 \%(\mathrm{w} / \mathrm{v})$ solution of trypsin (L. Light and Co., Colnbrook, Bucks.) were added to each 
bottle. After a $10 \mathrm{~min}$. incubation at $37^{\circ}$ most of the cells were pipetted off and transferred to a centrifuge tube. Each bottle was rinsed with $5 \mathrm{ml}$. balanced saline solution which was pooled with the cell suspension. Cellular clumps were broken up by vigorous pipetting and the suspension was centrifuged for $5 \mathrm{~min}$. at about $100 \mathrm{rev} . / \mathrm{min}$. After removal of the supernatant fluid, the cells from each bottle were resuspended either in $30 \mathrm{ml}$. medium I or in $50 \mathrm{ml}$. medium II to be transferred to three new bottles or to 100 tubes respectively. The cell suspension was dispensed into tubes $\left(3 \times \frac{5}{8}\right.$ in. Pyrex tubes) by means of an automatic syringe connected to a reservoir in which the cells were kept in suspension by a magnetic stirrer. Tubes were ready for use after overnight incubation at $37^{\circ}$, without rotation, at an angle of $5^{\circ}$ from the horizontal. Each tube then received $0.4 \mathrm{ml}$. of a $5 \%(\mathrm{v} / \mathrm{v})$ dilution of normal rabbit serum in balanced saline solution followed by $0 \cdot 1 \mathrm{ml}$. of the virus inoculum. The volume of medium/tube was thus made up to $1 \mathrm{ml}$. and the final concentration of lactalbumin hydrolysate was decreased to $0 \cdot 25 \%(\mathrm{w} / \mathrm{v})$. The tubes were re-incubated at $37^{\circ}$ and at intervals of 6 or 7 days the fluid from each tube was removed and replaced by $1 \mathrm{ml}$. of fresh medium III.

Virus preparation. The prototype strain of adenovirus type 5 was received from Dr R. J. Huebner (National Institutes of Health, Bethesda, Maryland, U.S.A.) and propagated in our laboratory through four passages in HeLa cell cultures. The material used throughout this work was obtained from two bottles containing each approximately $10^{7} \mathrm{HeLa}$ cells and $10 \mathrm{ml}$. of medium III, inoculated with $10^{6.5} 50 \%$ virus infective doses. After 4 days of incubation the total contents of the bottles were harvested and centrifuged for $10 \mathrm{~min}$. at $2000 \mathrm{rev} . / \mathrm{min}$. Nine-tenths of the supernatant fluid were decanted and the remaining volume, together with the cellular deposit, was ground in a TenBroeck tissue grinder and again centrifuged for $10 \mathrm{~min}$. at $2000 \mathrm{rev} . / \mathrm{min}$. The two supernatant fluids were pooled, divided into $1 \mathrm{ml}$. volumes and stored at $-15^{\circ}$.

Virus titrations. Serial dilutions of the virus preparation were made in broth saline $(10 \%, \mathrm{v} / \mathrm{v}$, tryptic digest broth in normal saline), using a fresh pipette for each dilution. Volumes of $0 \cdot 1 \mathrm{ml}$. of each dilution were added to each of thirty-two tubes of HeLa cells. The cultures were examined microscopically at suitable intervals for evidence of cytopathic effect. Tubes showing non-specific degeneration, usually due to incubation at an incorrect position or to loosening of bungs, were discarded.

\section{RESULTS}

\section{Dose-response curves}

Three titrations of the virus preparation were carried out at dilution ranges expected to give cytopathic effect end-points at 3, 9 and 20 days, respectively. The results of these titrations are shown in Table 1. The goodness of fit with the first and second terms of the Poisson distribution were estimated by the $\chi^{2}$ test according to the method recommended by Haldane (1939). The data were also submitted to probit analysis and the log dose-probit response curves 
Table 1. Adenovirus titrations read after varying periods of incubation

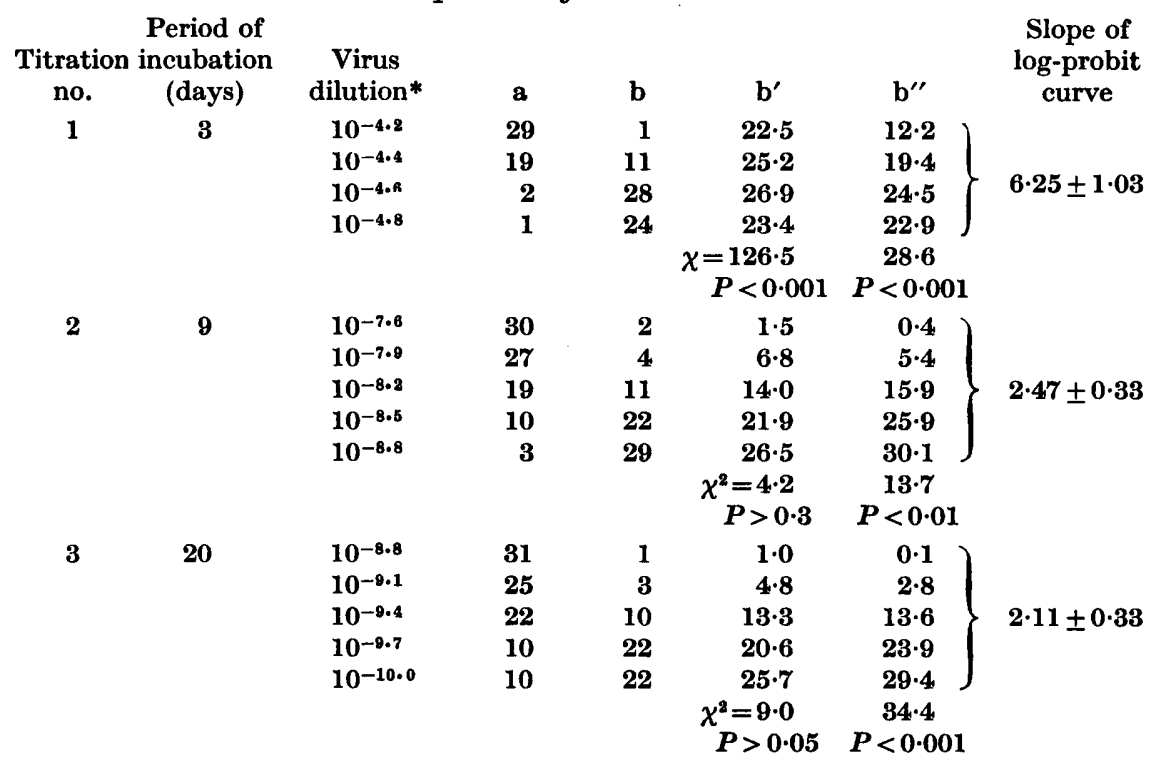

* Final dilution in $1 \mathrm{ml}$. of medium.

$a=$ number of positive cultures; $b=$ number of negative cultures; $b^{\prime}=$ expected number of negative cultures calculated from the first term of the Poisson distribution; $b^{\prime \prime}=$ expected number of negative cultures calculated from the second term of the Poisson distribution.

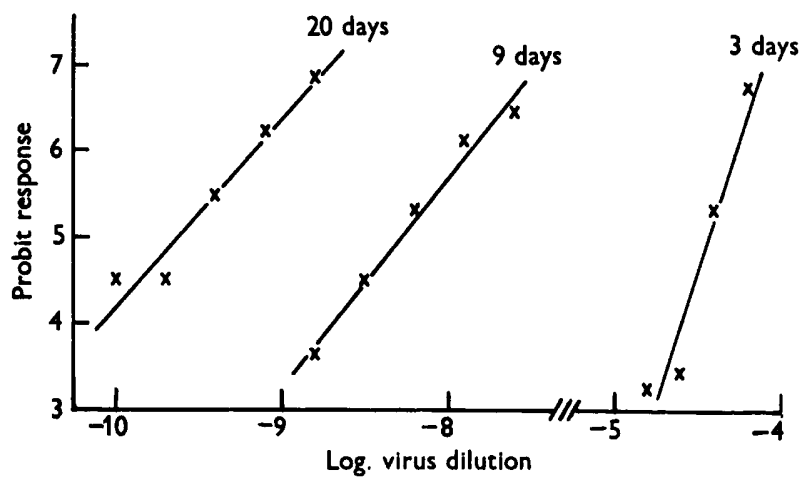

Fig. 1. Log dose-probit response curves of adenovirus titrations read after 3,9 and 20 days incubation.

are shown in Fig. 1. The 9- and 20-day curves vary in position along the abscissa but both show good agreement with the slope of the one-particle curve. The 3-day curve, on the other hand, differs markedly from these both in position and in slope. The difference between early and late readings is also illustrated by the inverse trend of $\chi^{2}$ values for goodness of fit with successive terms of the Poisson distribution. Another difference between early and late effects was revealed by the character of the cytopathic changes which were 
diffuse from start at the early readings whereas at the later readings, initial focal lesions were followed by gradual spread to the surrounding healthy cells.

The possible influence of age of the cultures on the slope of the dose-response curves was investigated by titrating the early cytopathic effect of the same virus preparation in cell cultures incubated for 7 days before addition of the virus inoculum. The result agreed closely with that of the titration done in cell cultures incubated for 1 day before inoculation. The $\chi^{2}$ test for goodness of fit with the one-particle curve gave a value of $16.76(n=3 ; P 0.001)$ and the slope of the log dose-probit response curve $(4 \cdot 80 \pm 0 \cdot 64)$ was not significantly different from the early reading obtained in the younger cultures.

\section{Effect of ultraviolet irradiation}

Two ml. volumes of a $10^{-2}$ dilution of the virus preparation were placed in $6.5 \mathrm{~cm}$. diameter Petri dishes and exposed for periods of 30,60 and $90 \mathrm{sec}$. to ultraviolet light at a distance of $30 \mathrm{~cm}$. from the source of light (Hanovia sun lamp). The original and each of the irradiated preparations were immediately diluted serially in broth saline in $\mathbf{0 . 5}$ log steps and titrated in cultures from a single batch of $\mathrm{HeLa}$ cells, four cultures being used for each dilution. The cultures were examined after incubation for 3 and 13 days and the $50 \%$ endpoints based on cytopathic effect were calculated by the method of Reed \& Muench (1938). The results shown in Table 2 reveal that the early cytopathic activity was not significantly affected in any of the samples, whereas the late effect was gradually reduced with increasing exposures to irradiation.

Table 2. End-points of early and late cytopathic effects of adenovirus treated by varying doses of ultraviolet light

\begin{tabular}{|c|c|c|c|c|}
\hline & \multicolumn{4}{|c|}{ Time of exposure to ultraviolet light (sec.) } \\
\hline & 0 & $\mathbf{3 0}$ & 60 & 90 \\
\hline $\begin{array}{l}\text { Early effect } \\
\text { (3-day reading) }\end{array}$ & 4.25* & $\mathbf{4} \cdot \mathbf{2 5}$ & $4 \cdot 25$ & 4.00 \\
\hline $\begin{array}{l}\text { Late effect } \\
\text { (13-day reading) }\end{array}$ & $8 \cdot 25$ & $7 \cdot 72$ & $7 \cdot 58$ & $6 \cdot 76$ \\
\hline
\end{tabular}

\section{COMMENTS}

Dose-response curves of virus titrations based on toxic effects have not, to our knowledge, been studied in detail. Rake \& Jones (1944), when studying the toxicity of meningo-pneumonitis virus, observed that titration end-points based on toxic activity followed a steeper slope than that of infectivity titrations of the same agent. A steep slope is also suggested by some of the figures reported by Henle \& Henle $(1946 a, b)$ in toxicity titrations of influenza viruses in mice. From the data recently published by Khoobyarian \& Walker (1957), on titrations of intravenous toxicity of influenza virus in mice, we have found that the dose-response curve in this system is significantly steeper than the one-particle curve with a slope of the log dose-probit response curve of 
$3.51 \pm 0.78$ and a $\chi^{2}$ for goodness of fit with the one particle curve of 18.25 $(n=4 ; \boldsymbol{P}<0.01)$. A search of the literature by Meynell \& Stocker (1957) revealed only two further examples of virus titrations with slopes significantly greater than 2. The first example (Parker, Bronson \& Green, 1941) refers to the titration of a low virulence strain of vaccinia virus which needed large doses to cause skin lesions in rabbits. The possibility of a toxic nature of these lesions should be kept in mind. In the second example (Luria \& Dulbecco, 1949) deviation from the one-particle curve was attributed to multiplicity reactivation of ultraviolet irradiated bacteriophages.

The different slopes of early and late adenovirus titration end-points might result from increasing variation in susceptibility of the cultures with age. This explanation can be ruled out by the fact that titrations of the early effect in cultures of different ages do not vary in slope.

The toxic nature of the cytopathic effect of adenoviruses has been suggested by Harford, Hamlin, Parker \& van Ravenswaay (1956) on the basis of electronmicroscopic study of HeLa cells infected with large doses of these agents. This suggestion finds support in the observation by Grayston, Johnston, Smith \& Loosli (1956), who pointed out the influence of the number of cells present in the cultures on the degree of cytopathic effect caused by adenovirus type 3 after incubation for 2 days. The inverse relation between number of cells and sensitivity to this effect indicates that multiplicity of infection may play a part in this phenomenon. The same is not the case in titrations based on late cytopathic effect (Pereira, unpublished).

The cytopathic effect of adenovirus in HeLa cells is considered as a manifestation of virus infectivity and our results agree with the hypothesis of initiation of infection by single infective units. The relation between infective units and virus particles cannot be determined without direct counts of the latter. The fact that titration end-points read after 9 and 20 days of incubation vary in position but not in slope may be an expression of the probability of occurrence of virus-cell interactions as a function of time. Further study of this aspect of the problem is in progress.

The distinction between toxic and infective activities is rendered difficult in the system under study by the high degree of susceptibility of HeLa cells to virus infectivity. Such a distinction has, however, been clearly demonstrated in the less susceptible cultures of rabbit kidney cells (Kelly \& Pereira, to be published).

Further work is required to extend the present findings to other adenovirus types and to determine whether the toxic effect observed is due to synergistic action of virus particles or to some soluble product present in the virus preparations. That this effect is associated with virus activity is evident from results of serum neutralization tests which are based on early cytopathic effects in the majority of techniques in use.

We are indebted to Drs A. W. Gledhill, A. Isaacs, J. Lindenmann and Miss M. V. Mussett for many helpful suggestions and to Mrs P. A. Palmer and Miss P. K. Pearce for valuable technical assistance. 


\section{REFERENCES}

Beard, J. W., Sharp, D. G. \& Eckert, E. A. (1955). Tumor viruses. Advanc. Virus Res. 3, 149.

Bryan, W. R. (1954). The relative precision of dose-response data in the virus and tumor fields as compared with that in certain other fields of biology. J. nat. Cancer Inst. 15, 305.

Bryan, W. R. (1955). Biological studies on the Rous sarcoma virus. I. General introduction. II. Review of sources of experimental variation and of methods for their control. J. nat. Cancer Inst. 16, 285.

Dulbecco, R. (1952). Production of plaques in monolayer tissue cultures by single particles of an animal virus. Proc. nat. Acad. Sci., Wash. 38, 747.

Feemster, R. F. \& Wells, W. F. (1933). Experimental and statistical evidence of the particulate nature of the bacteriophage. J. exp. Med. 58, 385 .

GEY, G. O. \& GEY, M. K. (1936). The maintenance of human normal cells and tumor cells in continuous culture. Amer. J. Cancer, 27, 45.

Grayston, J. 'T., Johnston, P. B., Smith, M. E. \& Loosli, C. G. (1956). An improved technique for the neutralization test with adenoviruses in HeLa cell cultures. J. infect. Dis. 99, 182.

HaLdane, J. B. S. (1939). Sampling errors in the determination of bacterial or virus density by the dilution method. J. Hyg., Camb. 39, 289.

Harford, C. G., Hamlin, A., Parker, E. \& van Ravenswayy, T. (1956). Electronmicroscopy of HeLa cells infected with adenoviruses. J. exp. Med. 104, 443.

Henle, G., Girardi, A. \& Henle, W. (1955). A non-transmissible cytopathogenic effect of influenza virus in tissue culture accompanied by formation of noninfectious hemagglutinins. J. exp. Med. 101, 25.

Henle, G. \& Henle, W. (1946). Studies on the toxicity of influenza viruses. I. The effect of intracerebral injection of influenza viruses. J. exp. Med. 84, 623.

Henle, W. \& Henle, G. (1946). Studies on the toxicity of influenza viruses. II. The effect of intra-abdominal and intravenous injection of influenza viruses. J. exp. Med. 84, 639.

Henle, W. \& Henle, G. (1947). The effect of ultraviolet irradiation on various properties of influenza viruses. J. exp. Med. 85, 347 .

IsaAcs, A. (1957). Particle counts and infectivity titrations for animal viruses. Advanc. Virus Res. 4, 111.

KhoObYaRIAN, N. \& WALKER, D. L. (1957). Effect of cortisone on mouse resistance to intravenous toxicity of influenza virus. Proc. Soc. exp. Biol., N.Y. 94, 295.

KJelles, L. (1956). Studies on adenoviruses (APC-RI-ARD) in tissue culture. Correlation between the amount of virus inoculated and the time needed for production of cellular degeneration. Arch. Virusforsch. 7, 110.

Laufrer, M. A. \& Price, W. C. (1945). Infection by viruses. Arch. Biochem. 8, 449.

Luria, S. (1939). Sur l'unité lytique du bactériophage. C.R. Soc. Biol., Paris, 130, 904.

Luria, S. (1940). Méthodes statistiques appliquées à l'étude du mode d'action des ultravirus. Ann. Inst. Pasteur, 64, 415.

Luria, S. E. \& Dulbecco, R. (1949). Genetic recombinations leading to production of active bacteriophage from ultraviolet inactivated bacteriophage particles. Genetics, 34, 93.

Meynell, G. G. \& Stocker, B. A. D. (1957). Some hypotheses on the aetiology of fatal infections in partially resistant hosts and their application to mice challenged with Salmonella paratyphi-B or Salmonella typhimurium by intraperitoneal injection. J. gen. Microbiol. 16, 38.

Parker, R. F., Bronson, L. H. \& Green, R. H. (1941). Further studies of the infectious unit of vaccinia. J. exp. Med. 74, 263.

Peto, S. (1953). A dose-response equation for the invasion of microorganisms. Biometrics, 9, 320. 
Rake, G. \& Jones, H. P. (1944). Studies on lymphogranuloma venereum. II. The association of specific toxins with agents of the lymphogranuloma-psittacosis group. J. exp. Med. 79, 463.

Reed, L. J. \& Muench, H. (1938). A simple method of estimating fifty percent endpoints. Amer. J. Hyg. 27, 493.

Rowe, W. P., Huebner, R. J., Grlmore, L. K., Parrott, R. H. \& Ward, T. G. (1953). Isolation of a cytopathogenic agent from human adenoids undergoing spontaneous degeneration in tissue culture. Proc. Soc. exp. Biol., N.Y. 84, 570.

Sheffield, F. W. \& Smith, W. (1956). The titration of Lansing poliomyelitis virus in HeLa cell cultures. Brit. J. exp. Path. 37, 5.

(Received 25 April 1957) 